\title{
Morphogenetic diagnosis of developmental changes of Sea arrowgrass fruit (Triglochin maritima L.)
}

\author{
Cezary Toma ${ }^{1}$, Andrew N. Efremov², Wioleta Josefowska ${ }^{3}$ \\ ${ }^{1}$ Department of Carpology, Institute of Environmental Biology, Faculty of Natural Sciences, Kazimierz Wielki University, \\ Chodkiewicza 30, 85-093 Bydgoszcz, Poland, e-mail: cezarytoma@poczta.onet.pl (corresponding author) \\ ${ }^{2}$ Biological Department, Faculty of Sciences Education, Omsk State Pedagogical University, Nab. Tukhachevskogo 14, \\ 644009 Omsk, Russia, e-mail: stratiotes@yandex.ru \\ ${ }^{3}$ Department of Botany and Genetics, Institute of Biology and Environmental Protection, Faculty of Mathematics and Natural Sciences, \\ Pomeranian University, Arciszewskiego 22,76-218 Słupsk, Poland, e-mail: wioletajosefowska@wp.pl
}

\begin{abstract}
Abstact: The aim of the study was to investigate the morphogenesis of particular developmental stages of T. maritima fruits; from the stage of the bud to the ripe fruit with the use of a scanning electron microscope (SEM), to learn about the morphology and anatomy of ripe fruit, find new diagnostic features of the fruits and verify T. maritima. fruit diagnosis. An optic microscope and Met - Ilo 8 image analyzer were used in the research. In the final part of the research, the occurrence of two diagnostic features was confirmed and seven new diagnostic features of ripe T. maritima fruit were demonstrated. The morphological development of T. maritima fruits is characterized by significant qualitative and quantitative changes of diagnostic value. The range of the changes in the size of T. maritima generative structures is well characterized by the data obtained from the image analyzer. T. maritima fruit diagnosis: dry, indehiscent achene partly syncarpic.
\end{abstract}

Key words: morfogenesis, fruit, seed, carpology, pericarp

\section{Introduction}

Sea arrowgrass belongs to a subclass of Alismatidae (Szweykowska and Szweykowski 2006). It is a member of the Triglochin genus and the Scheuchzeriaceae family (Szafer et al. 1986) or to the Juncaginaceae family (Rutkowski 1998). T. maritima is a holarctic and antarctic species (Hegi 1981). It occurs in wet habitats, peat and salty meadows. In Poland, it grows along the Baltic, more rarely further inland. It is common in colder areas with moderate climate. It grows in northern and southern Europe as far as Portugal, northern and central Italy and Bulgaria, but it does not grow on the Atlantic islands. It also occurs in northern Siberia, northern Africa, Asia and North and South America (Raciborski and Szafer 1919; Hegi 1981). T. maritima has different chromosome numbers $2 \mathrm{n}=24,28,36,48,80,120$ (Guo et al. 2010).

T. maritima has been assigned to the following taxa according to different classifications. According to the Takhtajan system (Takhtajan 2009), it belongs to the subclass of Alismatidae, the order of Juncaginales, sub- order of Juncaginaceae and the Juncaginaceae family. In the system of plant taxonomy by Kubitzki (1998), T. maritima belongs to the superorder of Alismatanae, the order of Alismatales, the family of Juncaginaceae. In the system of plant taxonomy by Thorn (1992), $T$. maritima belongs to the superorder of Alismatanae, the order of Potamogetonales, the suborder of Potamogetonaceae, the family of Juncaginaceae. According to Walters (1980) plant taxonomy system T. maritima belongs to the order of Helobiae, the family of Juncaginacae. According to Rutkowski (1998) and Szweykowska and Szweykowski (2006), T. maritima belongs to the subclass of Alismatidae, the order of Alismatales, the family of Juncaginaceae. According to the Angiosperm Phylogeny Website APG III T. maritima belongs to clad Monocots, order of Alismatales, family Juncaginaceae (Stevens 2001).

Raunkiaer (1934) classified T. maritima as a hemicryptophyte whose buds hibernate on the surface of the soil during winter. This species is a member of the group of air-water plants according to Szennikow (1952). The characteristics of Triglochin species and Juncaginaceae 
family are described in the floras of Raciborski and Szafer (1919), Holm-Nielsen and Haynes (1986), Crow and Hellquist (1982), Lisowski et al. (1982), Jafri (1977), Haynes et al. (1998), Haynes (2004) and in other studies, e.g. by Mowszowicz (1977). The distribution of T. maritima species in Poland was demonstrated by Sotek (2001). The general development of the plant, the structure of its leaves and germination of T. maritima seeds was presented by Hill (1900), Arber (1924), Davy and Bishop (1991). The structure of the inflorescence was presented by Charlton (1981). Early stages of the development of T. maritima flowers were presented by Wu at al. (2008). However, the subject literature contains few reports on the development and structure of T. maritima. Toma (2008) described the fruit development and morphological and anatomical features of Triglochin palustre L. ripe fruit.

The aim of this study is to investigate the morphological and anatomical structure of ripe T. maritima fruit and its morphological development, to conduct an analysis of changes to the size of buds, pistils, flowers and fruits with an image analyzer as well as a verification of T. maritima fruit diagnosis.

\section{Study area}

The study area is located around the Szczecin Lagoon (Zalew Szczeciński) that belongs to the mesoregion of the Uecker Plain (Równina Wkrzańska), the macroregion of Szczecin Coastland (Pobrzeże Szczecińskie), subprovince of the South Baltic Coastlands, the province of the North European Plain, and the megaregion of Non-Alpine Central Europe (Kondracki 2002). The neighbouring mesoregions surrounding the Uecker Plain are: the Lower Oder Valley (Dolina Dolnej Odry) to the east, and Szczecin Hills (Wzgórza Szczecińskie) to the south. The Uecker Plain comprises the area near the border between Poland and Germany and the area that belongs to Poland is about $337 \mathrm{~km}^{2}$. Most of the area is covered by pine trees and is called Ueckermünde Heath (Puszcza Wkrzańska) (Kondracki 1994, 2002).

In the commune of Nowe Warpno the soils used for agricultural activity are bad quality, $98 \%$ of arable land and $76 \%$ of grasslands are classified as poor quality-sandy soils (class V and VI). There are peaty and marshy soils in the wetland (Miluniec et al. 2005). Due to its location, the climate of the town of Nowe Warpno has the qualities of the marine climate which can be observed in the air humidity, significant precipitation and short winters. It is characterized by great variety and changeability, small annual temperature variations, high humidity and windiness, cool summers and mild winters. The vegetative period lasts 220 days on average (Miluniec et al. 2005; Borówka 2002).

\section{Materials and methods}

T. maritima generative shoots containing flower buds, flowers and fruits constituted the research material. The material was collected in the area of Karszno village, currently a part of the town of Nowe Warpno, in June and July 1999. T. maritima was identified using Szafer's key (1976), Mądalski (1977) and Hegi (1981). Generative shoots with seeds and flowers were dried as a part of the research material, the rest of the material consisted of parts of shoots with buds, flowers and fruits preserved in FAA (ethyl alcohol 90\%, acetic acid $5 \%$, formalin 5\%) and glutaraldehyde. An observation of morphological and anatomical features of particular developmental stages of T. maritima fruit was carried out with the help of a stereo microscope MST 132 (produced by Polish Optical Industries). The material was preserved in glutaraldehyde and observed with a Jeol JSM-5500LV scanning microscope using the low vacuum function. The research material is located at the Department of Carpology of Kazimierz Wielki University in Bydgoszcz.

In the description of the micromorphology of the fruit surface the following terms were applied: cell pattern, primary and secondary surface sculpture (Boesewinkel and Bouman 1984).

Younger stages of T. maritima fruit development showed higher sensitivity to dehydration in SEM research. The measurements of the length, width, surface, perimeter and the shape coefficient of the examined structures were carried out with a Met-Ilo 8 image analyzer. The division into four developmental stages was done on the basis of observation of the flower and fruit morphology, taking into consideration the size of their structures and the degree of their formation. The number of buds, flowers, young fruits and ripe multiple fruits were determined on a 10-centimeter-long generative shoot. The shape coefficient used in the description of the morphology of pistils, fruit, inflorescence and multiple fruit is a dimensionless quantity. The value of this feature falls in the range from 0 to 1 . Organs with a value close to zero are flat and those close to one are circular. The measurements were taken 10 times from buds, flowers, fruits and generative shoots. The following abbreviations were applied: L - length, $\mathrm{W}$ - width, A - surface area, $\mathrm{P}$ - perimeter, $\mathrm{SC}$ - shape coefficient.

\section{Results}

\section{Characteristics of $T$. maritima generative organs at stage 1}

Morphology of the bud

T. maritima flower buds are alternate on the generative shoot and connate to each other. 398-405 buds were 
observed on the 10-centimeter long section of the generative shoot. A short pedicel of the bud is perpendicular to the outer surface of the generative shoot. In the flower, there are six elongated pistils which are broader at the base and narrow at the apex. The measurements of the bud are: $\mathrm{L}-1.46-1.78 \mathrm{~mm}, \mathrm{~W}-1.55-1.90 \mathrm{~mm}$, A - 2.20-2.90 $\mathrm{mm}^{2}, \mathrm{P}-5.17-6.53 \mathrm{~mm}, \mathrm{SC}-0.84-0.88$ (Fig. 1).

\section{Morphology of the carpel}

The carpel stigma is large, located at an angle of $45^{\circ}$ to the transverse axis of the carpel. It is $1 / 3$ of the total length of the carpel. In the transverse section of the carpel, it is broader in the centrifugal section and narrow in the centripetal section. The carpel measurements are: $\mathrm{L}-0.55-0.75 \mathrm{~mm}, \mathrm{~W}-0.24-0.35 \mathrm{~mm}, \mathrm{~A}$ - 0.12-0.15 $\mathrm{mm}^{2}, \mathrm{P}-1.50-1.90 \mathrm{~mm}, \mathrm{SC}-0.48-0.55$ (Fig. 2).

\section{Micromorphology of the carpel}

The cell pattern is invisible. The outer surface of the epidermis of the carpel wall has irregular undulations. The original sculpture is invisible. The anticlinal walls are elevated and the edges of the undulations are smooth. The periclinal walls are lowered and slightly undulated or smooth. The secondary sculpture is invisible. There are stomata in the outer epidermis of the pistil wall. Stomata are distributed irregularly (Fig. 3).

\section{Characteristics of $T$. maritima generative organs at stage 2}

Morphology of the flower

The T. maritima inflorescence is raceme. The flowers are located alternately on the generative shoot. There are 85-95 flowers on the 10-centimeter long section of the generative shoot. The flowers grow acropetally on the shoot. The $1.5 \mathrm{~mm}$ long flower pedicels are located at an angle of $45^{\circ}$ to the main axis of the generative shoot. There are two swellings on the pedicel. Elements of the perianth are attached to the first one while the other contains pistils. The scaly elements of the perianth attached to the pollen sacks are partly opened and placed in two whorls (Fig. 4). There are six pollen sacks in the flower with two pairs of stamens without filament placed in two whorls. The pollen stacks of the second whorl are attached to the pistil at the base and their length is approximately the same length as the perianth elements. The flower contains six fully mature carpels whose apical parts are elevated over the edge of the perianth with salient stigmata at the end. The flower measurements are: $\mathrm{L}-2.55-3.88 \mathrm{~mm}, \mathrm{~W}-$ $1.65-2.45 \mathrm{~mm}, \mathrm{~A}-3.80-6.45 \mathrm{~mm}^{2}, \mathrm{P}-8.12-9.62 \mathrm{~mm}$, SC $-0.62-0.70$.

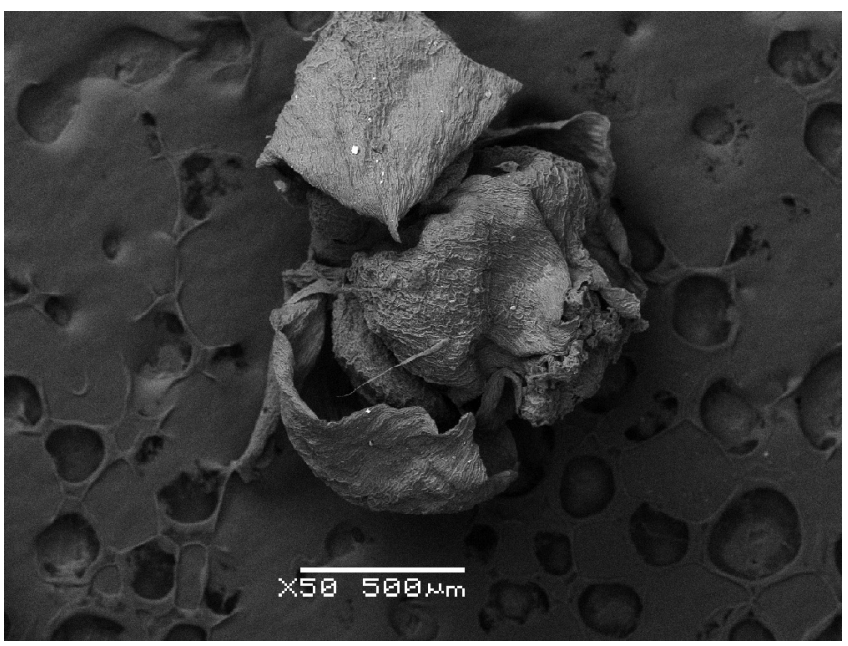

Fig. 1. SEM photography of bud of T. maritima at stage 1

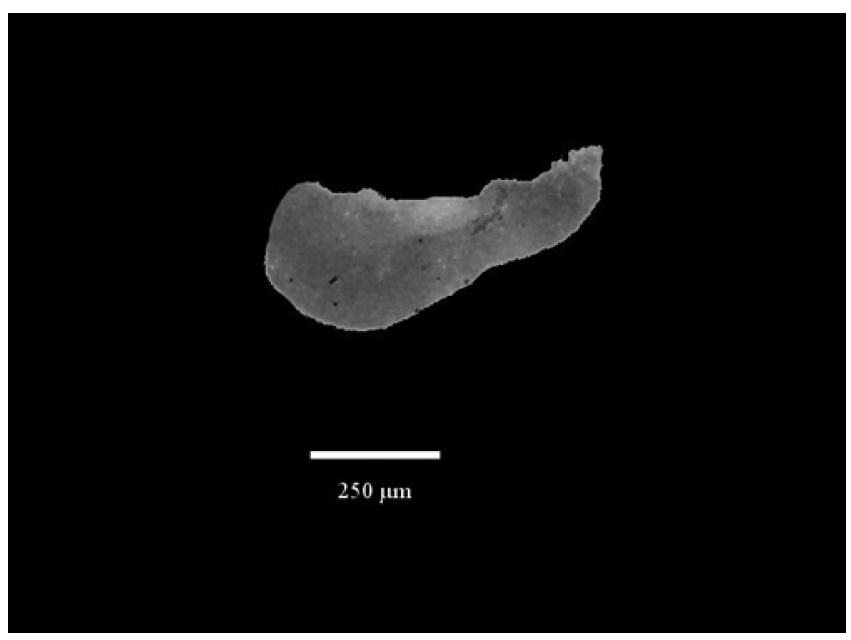

Fig. 2. SEM photography of T. maritima carpel at stage 1

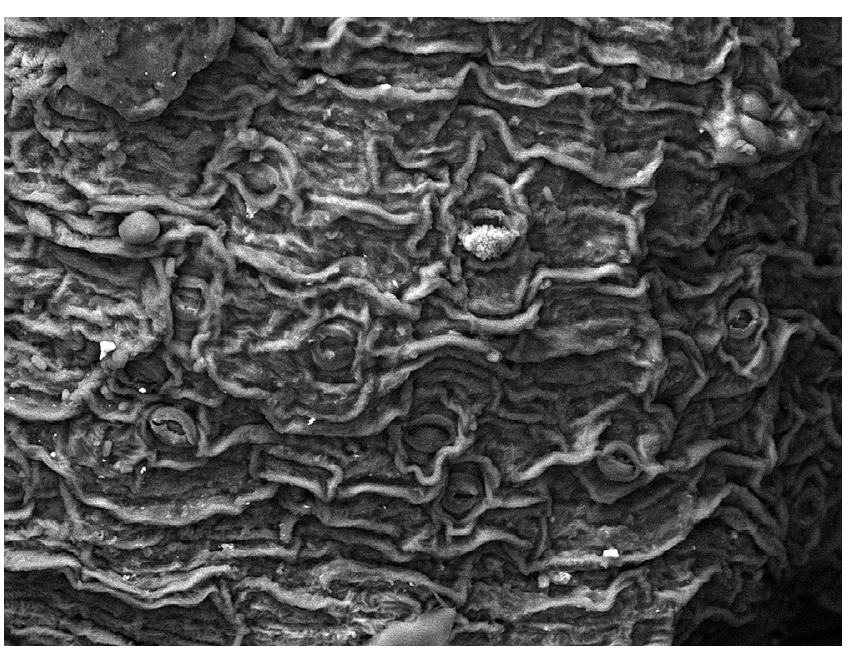

Fig. 3. SEM photography of outer surface of epiderma of T. maritima carpel at stage 1 


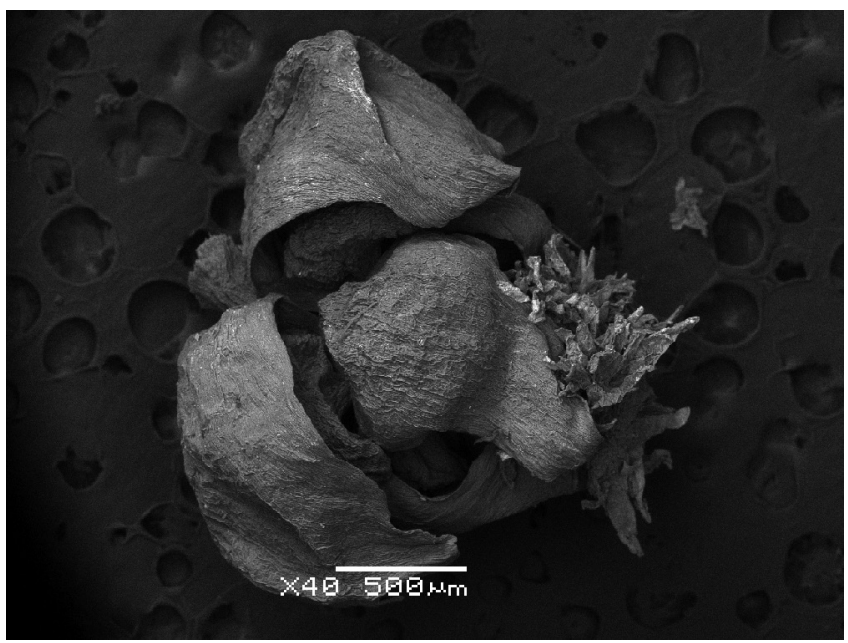

Fig. 4. SEM photography of flower of T. maritim at stage 2

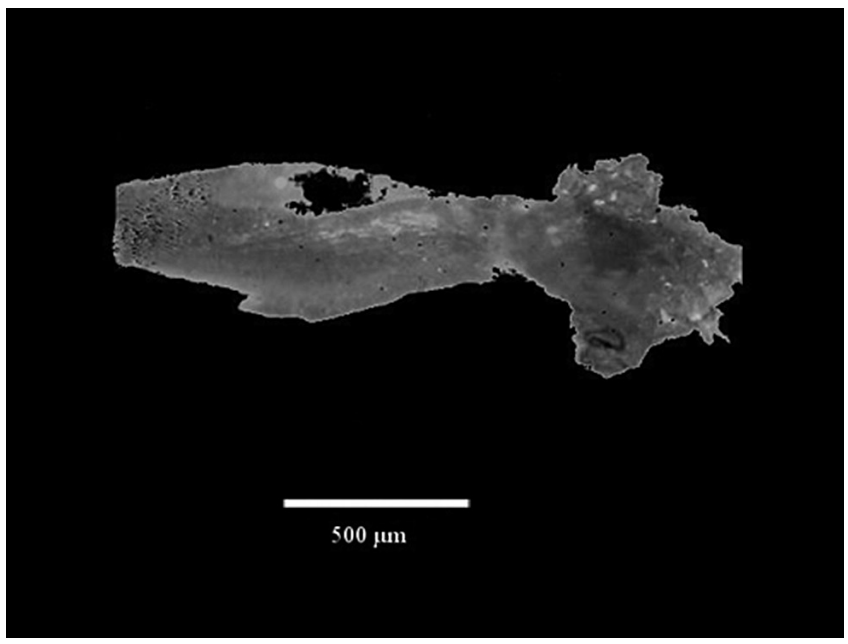

Fig. 5. SEM photography of T. maritima carpel at stage 2

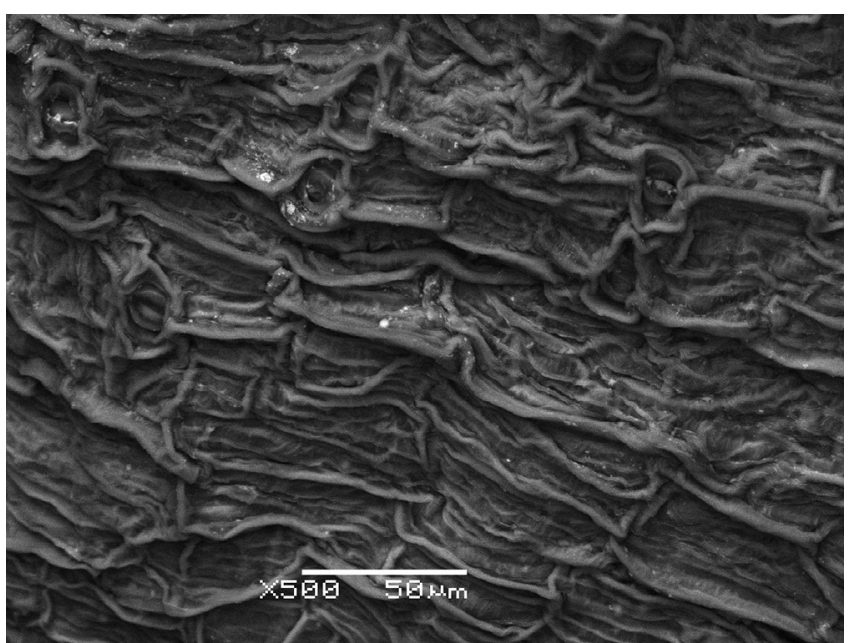

Fig. 6. SEM photography of outer surface of epiderma of T. maritima carpel at stage 2
Morphology of the carpel

The carpel is significantly elongated, oval with an apical stigma. The stigma constitutes $1 / 3$ of the total length of the pistil. The stigma is jagged. The carpel measurements are: $\mathrm{L}-1.20-1.80 \mathrm{~mm}, \mathrm{~W}-0.38-0.75$ $\mathrm{mm}, \mathrm{A}-0.45-0.62 \mathrm{~mm}^{2}, \mathrm{P}-3.62-4.85 \mathrm{~mm}, \mathrm{SC}-0.32-$ 0.34 (Fig. 5).

\section{Micromorphology of the carpel surface}

The cell pattern is invisible. The outer epidermis of the pistil is irregular. The undulations on the outer epidermis surface are distributed longitudinally along the pistil axis. The borders of the cells making up the outer pistil epidermis are difficult to recognize. The original sculpture of the surface is invisible. The ribs of the undulations are smooth. The secondary sculpture is invisible. There are six tetracytic stomata all over the outer surface of the epidermis of the pistil (Fig. 6).

\section{Characteristics of T. maritima generative organs at stage 3}

Morphology of young fructification

Fructification is oval in shape and broader at the base. There are 58-61 young fruits on the $10 \mathrm{~cm}$ long section of the generative shoot. T. maritima organs of fruiting consist of six fructifications so there are 10-12 fruits on the $10-\mathrm{cm}$ long section. Flower pedicels are located at an angle of $45^{\circ}$ to the main axis of the generative shoot. The flower pedicel has two swellings and the elements that fall off the flower are attached to the first one. The six fruits are set in a whorl and attached to the second swelling on the flower pedicel which is circular. The measurements of young fructification: $\mathrm{L}$ - 3.42-5.07 mm, W - 2.61-2.90 mm, A - 11.89-13.22 $\mathrm{mm}^{2}, \mathrm{P}-15.80-16.39 \mathrm{~mm}, \mathrm{SC}-0.57-0.70$.

\section{Morphology of young fruit}

Young fruit is significantly elongated and the flower pedicel is $3 \mathrm{~mm}$ long. In the lower part of the fruit elements of the perianth and remains of pollen sacks are visible, they are about $1 / 3$ of the young fruit length (Fig. 7). The centrifugal part of the fruit is broader while the centripetal part is significantly narrow. The remains of the stoma are visible in the apical part of the fruit. The middle section of the young fruit becomes connate with the column in the middle of the fructification. The measurements of single young fruit are: $\mathrm{L}-2.61-3.01$ $\mathrm{mm}, \mathrm{W}-0.85-0.95 \mathrm{~mm}, \mathrm{~A}-1.80-2.20 \mathrm{~mm}^{2}, \mathrm{P}-7.50$ $8.90 \mathrm{~mm}, \mathrm{SC}-0.38-0.40$ (Fig. 8).

Micromorphology of the surface of young fruit

The cell pattern is irregularly reticular. The primary sculpture is made up of cells of various shapes. The cells are medium size: mean length $-58.6 \mu \mathrm{m}$, mean width 
$-40.9 \mu \mathrm{m}$. The anticlinal cell walls of the outer epidermis of the fruit are elevated and smooth. The periclinal walls are lowered and smooth. The secondary structure is slightly undulated. Four stomata of tetracytic type are visible on the outer fruit epidermis (Fig. 9).

Characteristics of $T$. maritima generative organs at stage 4

Morphology of ripe fructification

Fructification is oval and has the shape of a flattened sphere. There are 39-41 ripe fruit on the $10-\mathrm{cm}$-long section of the generative shoot which make up six separate fructifications. The pedicel of the fructification, 4 $\mathrm{mm}$ long, grows at a $45^{\circ}$ angle to the axis of the generative shoot. It has two swellings the first of which is free while the other has fruits attached to it and has the

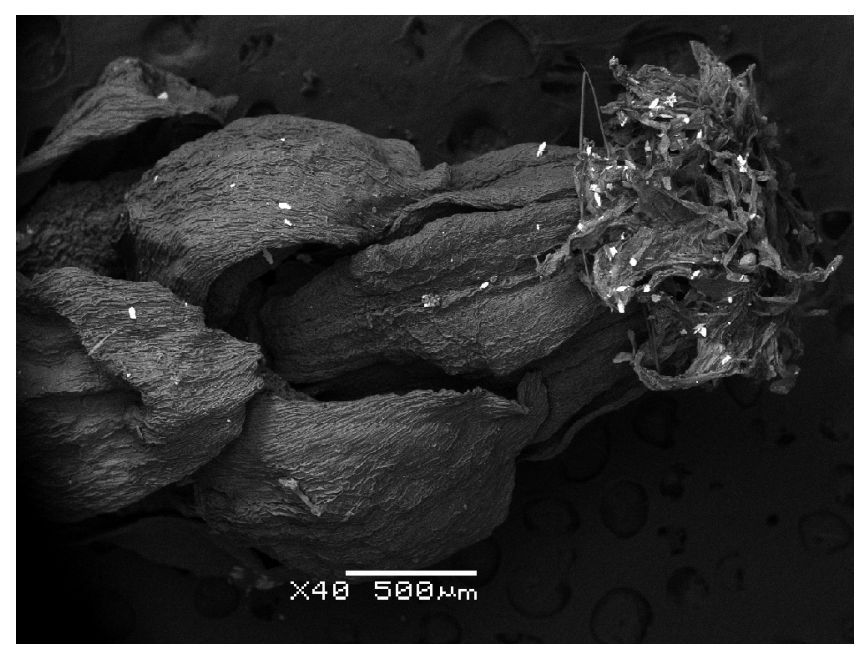

Fig. 7. SEM photography of young fruit of T. maritima at stage 3

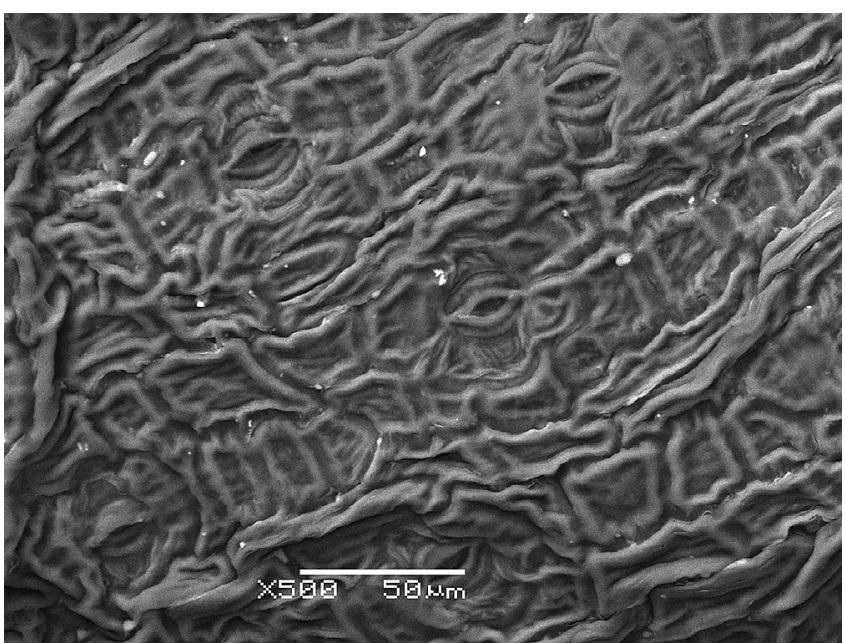

Fig. 9. SEM photography of outer surface of epiderma of T. maritima young fruit at stage 3 shape of three semi-circles that are connate to each other. Two fruits grow out of each semicircle. The measurements of ripe fructification are: $\mathrm{L}-5.80-6.20 \mathrm{~mm}, \mathrm{~W}-$ 2.80-3.10 mm, A - 12.20-16.50 mm², P - 15.00-17.20 $\mathrm{mm}, \mathrm{SC}-0.65-0.69$.

Morphology of ripe fruit

Ripe fruit is a flattened semicircle in the shape of a spherical sector which is broader in its centrifugal section and narrow in its centripetal section. It is triangular in cross section. The fruits become connate in the centripetal section with a column in the middle of the fructification (Figs 10-11). The measurements of a single ripe fruit are: $\mathrm{L}-4.60-6.00, \mathrm{~W}-1.22-1.60 \mathrm{~mm}, \mathrm{~A}$ - 5.10-6.50 $\mathrm{mm}^{2}, \mathrm{P}-12.80-13.50 \mathrm{~mm}, \mathrm{SC}-0.41-0.45$ (Fig. 12).

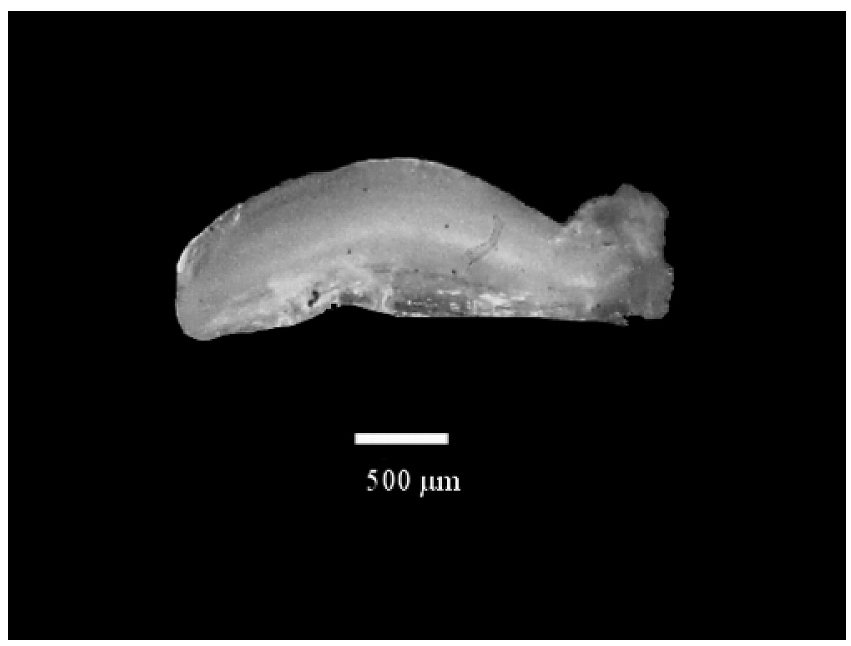

Fig. 8. SEM photography of T. maritima young fruit at stage 3

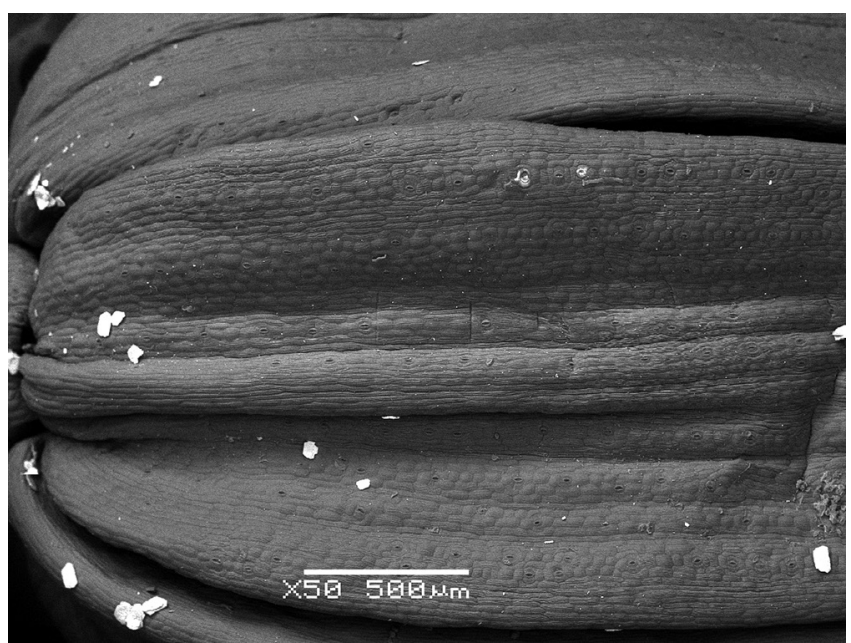

Fig. 10. SEM photography of basal part of T. maritima mature fruit at stage 4 


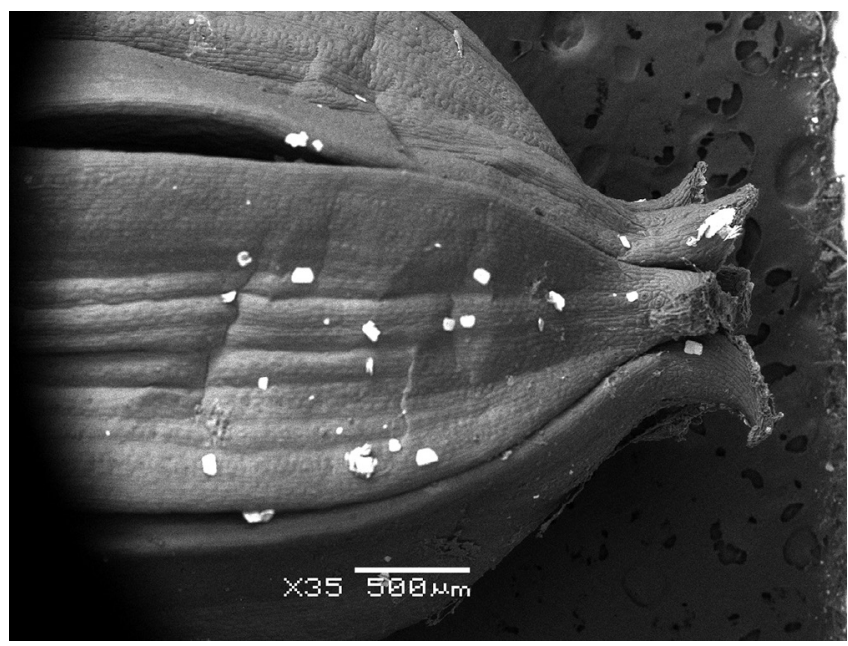

Fig. 11. SEM photography of apical part of T. maritima mature fruit at stage 4

Micromorphology of the surface of ripe fruit

The cell pattern of the centripetal surface of the fruit is varied. Rows of cells containing stomata and rows of cells without stomata are visible. The section without stomata contains rectangular cells, sometimes with sharp ends. The section of the surface with stomata contains square or hexagonal cells. On the outer surface of the fruit, $4-5$ rows of cells containing stomata are visible. The cell pattern is irregular and reticular. The cells of the outer epidermis of ripe fruit are almost square: in length $-74.1 \mu \mathrm{m}$, and width $-69.1 \mu \mathrm{m}$ or rectangular: in length $-121.2 \mu \mathrm{m}$, and width $-37.1 \mu \mathrm{m}$. The anticlinal walls are elevated and smooth. The periclinal walls are lowered and transversely undulated. The secondary sculpture is slightly undulated. Three tetracitic stomata can be observed (Fig. 13).

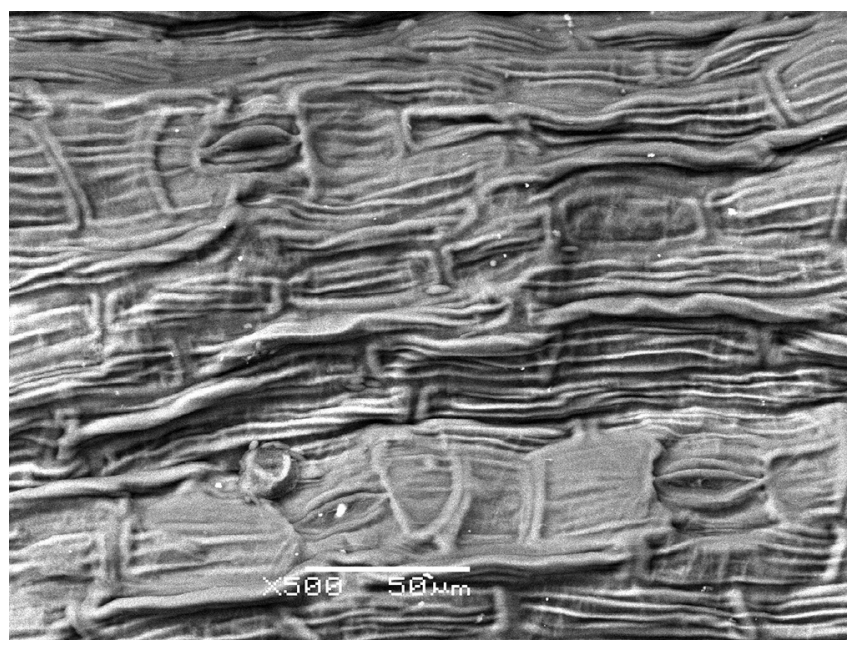

Fig. 13. SEM photography of outer surface of epiderma of T. maritima mature fruit at stage 4

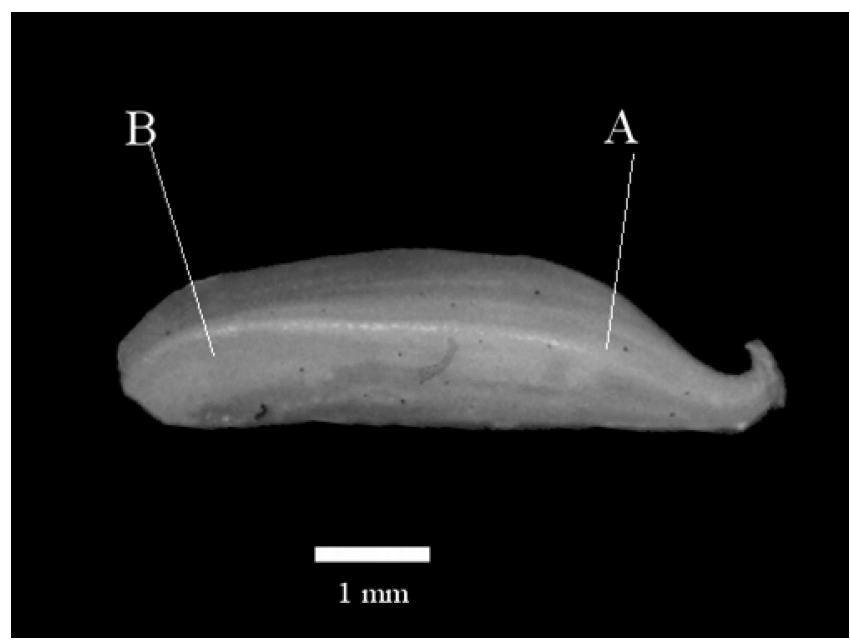

Fig. 12. SEM photography of T. maritima mature fruit at stage 4: A - apical part of the fruit, B - basal part of the fruit

Anatomy of fructification and pericarp

Fructification is built from six chambers. Centripetal edges of the chambers connate with each other and with a centrally located column. There is one oblong seed in each fruit chamber which is located in its centrifugal section. The seed looks like a clumsy $\mathrm{C}$ letter with rounded ends. The seed dimensions are: length $1.95-2.15 \mathrm{~mm}$, width $-0.29-0.32 \mathrm{~mm}$. The pericarp is made up from three layers of cells: egzocarp, mesocarp and endocarp (Fig. 14).

One-layer endocarp is the outermost layer of the pericarp and its cells have thin walls and are slightly elongated, their measurements are: mean length -22.8 $\mu \mathrm{m}$, mean width $-17.3 \mu \mathrm{m}$. In the middle section, there are 2-3 layers of thin-walled cells of the mesocarp of mean length $-52.1 \mu \mathrm{m}$, mean width $-44.6 \mu \mathrm{m}$. The

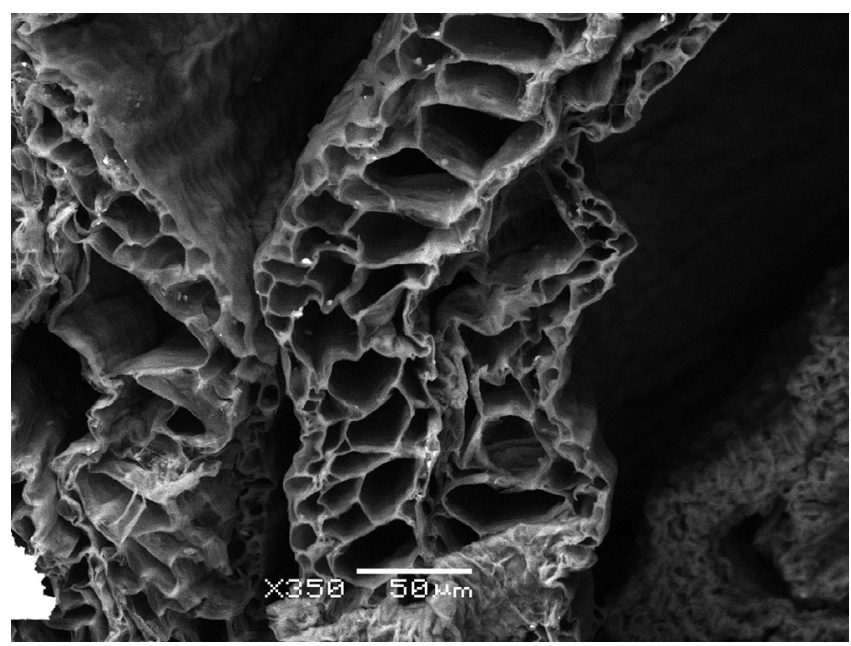

Fig. 14. SEM photography of cross-section of pericarp of T. maritima mature fruit at stage 2 
longitudinal axis of these cells is perpendicular to the longitudinal axis of the endocarp cells. A single-layer of thin-walled egzocarp is the outermost. The measurements of the egzocarp cells are: mean length $-19.6 \mu \mathrm{m}$, mean width $-17.0 \mu \mathrm{m}$.

\section{Discussion}

T. maritima fruit has been classified as a six-member schizocarp (Rutkowski 1998), the fruit splits into six oval schizocarps (Szafer et al. 1976), achene (Mądalski 1977; Tomlinson 1982), schizocarp with 1-seed mericarp (Dahlgren et al. 1985), or nut (Dandy 1980; Kubitzki 1998).

According to the definition, achenes are one-seed, dry, indehiscent fruit with a single chamber containing one seed. The seed testa and the fruit wall adhere to each other closely but do not connate (Tootill 1984; Harris and Harris 1994). The definition of the nut says that it is a hard, dry and indehiscent usually one-seed fruit. It originates from more than one pistil but contains only one seed while others get aborted. Nutlets are understood as small nuts typical of the Lamiaceae family. The term nut is often used to refer to any hard fruits and seeds (Tootill 1984; Harris and Harris 1994). The schizocarp is a dry fruit that originates from a few one-chamber pistils which split into one-seed units at maturation (Tootill 1984; Spjut 1994). The obtained data on the development of T. maritima fruits support the thesis that this genus fruit are achenes.

The generative organs of two related species of $T$. palustre and T. maritima differ significantly in terms of morphology and anatomy despite belonging to the same genus. The most important difference is the number of pistils and fruit that grow in one fructification of the plant. There are six pistils and six fruits in T. maritima while T. palustre have half the number of both (Szafer et al. 1986; Rutkowski 1998; Toma 2008). Comparing individual developmental stages of T. maritima and $T$. palustre, more important differences can be observed between the two species. At the first and second stages there are small differences in the width and length of the pistils in both species. The outer layer of the T. mariti$m a$ pistil epidermis surface contains stomata at stage 1 and 2 which are missing in the T. palustre epidermis. At stage 3 of the young fruit, there are differences between the two species in terms of the measurements of the epidermis cells. T. maritima cells are longer and wider than T. palustre cells. The length of the young fruits of both species are actually similar, however, T. maritima fruits are slightly wider. At the ripe fruit stage, i.e. stage 4 , all cells that create the pericarp have thin cell walls in T. maritima while in T. palustre they are thick. A characteristic feature to distinguish between the two species at the ripe fruit stage is the occurrence of rows of cells in the T. maritima epidermis which are rectangular and contain stomata and rows of hexagonal and square cells that do not contain stomata. A ripe T. maritima fruit is wider than T. palustre fruit by $0.55 \mathrm{~mm}$ and shorter than T. palustre fruit by $2.33 \mathrm{~mm}$. A single T. maritima fruit at stages 3 and 4 is wider basally and narrow in the apical section; however, T. palustre fruit is narrow basally and apically. The T. palustre chamber may contain 1 or 2 seeds (Rutkowski 1998; Toma 2008), while in $T$. maritima there may be only one seed in one chamber. The T. palustre seed is oval and $3.00 \mathrm{~mm}$ long (Toma 2008), while the T. maritima seed is $2.05 \mathrm{~mm}$ long and is elongated and slightly bent.

Another characteristic difference between the two species is the position of periclinal and anticlinal walls. In T. maritima periclinal walls are lowered and transversely undulated (stage 4 ) or smooth (stage 3 ); the anticlinal walls are elevated and smooth (stages 3 and 4). However, in T. palustre periclinal walls are smooth and anticlinal walls are lowered, straight or slightly bent at stages 3 and 4 (Toma 2008). Comparing the generative organs' shape coefficient of both species, it can be observed that it decreases in T. palustre, i.e., the value of the shape coefficient approaches zero, while in T. maritima it decreases between the first and the second stage and gradually increases between the second, third and fourth stage of the fruit development.

Changes in the development of T. maritima fruit are irregular between subsequent stages. Taking into consideration different parameters that describe particular structures and organs, it can be stated that the greatest differences in length and width occur between stage 3 and stage 4 . Comparing the shape coefficient of inflorescences and fructifications as well as pistils and fruits, stages 1 and 4 are characterized by a parameter value close to one. The biggest growth of the fruit pedicel occurs between stages three and four. The highest number of buds was observed on a $10-\mathrm{cm}$-long section of the generative shoot at stage one. The proportion of the length to the width of the pistils and fruits increases between stage one and two and between stages three and four and it decreases between the second and third stages. Comparing the proportion of the length to the width of the inflorescences and fructifications, a slight increase can be observed between stages one and two and between stages three and four; however, the highest increase occurs between stages two and three.

The occurrence of a column linking the fruits at stages three and four is characteristic of T. maritima species. The fruit columns connate in their centripetal section. This is an example of a syncarpic fruit development. Another feature is the occurrence of an acropetal increase of generative structures on the shoots. Still an- 
other important feature is the occurrence of differences between outer epidermis cells at stages three and four. The surfaces of the epidermis of young fruits create cells of varied shapes, while the epidermis cells of ripe fruits are represented by two types: longitudinal cells and quadrilateral cells.

Features that may be applied to diagnose T. maritima species can be divided into morphological and anatomical ones. The morphological features include: (i) The number of seed chambers, (ii) The number of seeds in one chamber, (iii) The length of the shoot of the flower pedicel, (iv) The size and the shape of the epidermis cells of young and ripe fruits, (v) The position of periclinal and anticlinal walls of the fruit epidermis, (vi) The distribution and types of stomata in the ripe fruit epidermis. The anatomical features include: (i) The number of layers of the pericarp cells, (ii) The measurements of the pericarp cells, (iii). The thickness of the pericarp walls.

T. maritima fruit is diagnosed as achene. T. maritima fructification consists of six single fruits that connate at the column. The range of developmental changes in $T$. maritima is characteristic of the species and may be applied for diagnostic purposes. The research confirmed the features T. maritima used in the keys for fruit determination and revealed new features of diagnostic value. The demonstration of new features characteristic of T. maritima fruits will enable a full diagnosis in relation to fresh material and determination of paleo macro-remains. The outer surface of the epidermis of generative organs may also be used for diagnosis, which is confirmed by proving the features that distinguish particular stages of development from one another. The Met-Ilo 8 image analyser used in the research depicts the changes in shape of both ripe and developing fruits well.

\section{Conclusion}

The morphological development of T. maritima is characterized by considerable qualitative and quantitative changes of diagnostic value. The occurrence of two diagnostic features was confirmed and seven new diagnostic features of T. maritima fruits were demonstrated, which completes the existing taxonomy of the species and thus enables a better diagnosis. The range of the changes in the size of T. maritima generative structures are well characterized with the data obtained from the Met-Ilo 8 image analyser. The diagnosis of T. maritima fruit: dry, indehiscent achene, partly syncarpic.

\section{References}

Arber A., 1924, Leaves of Triglochin, Bot. Gaz. 77(1): 50-62. Boesewinkel F. D., Bouman F., 1984, The seed: Structure, [in:] Johri B.M. (ed.), Embryology of angiosperms, Springer, Berlin-Hadelberg-New York-Tokyo: 597-610.

Borówka R., 2002, Środowisko geograficzne (Geographic environment), [in]: Kaczanowska M. (ed.), Przyroda Pomorza Zachodniego (The natural world of Western Pomerania), Wydaw. Oficyna in Plus, Szczecin: 6-105.

Crow G.E., Hellquist C.B., 1982, Aquatic vascular plants of New England. Part 4. Juncaginaceae, Scheuchzeriaceae, Butamaceae, Hydrochataceae, New Hampshire Agric. Exp. Sta. Bull. 520: 1-34.

Charlton W.A., 1981, Features of the inflorescence of Triglochin maritime, Can. J. Bot. 59(11): 2108-2115.

Dahlgren R.M.T., Clifford H.T., Yeo P.F., 1985, The Families of the Monocotyledons: Structure, Evolution, and Taxonomy, Springer, Berlin-New York, 520 pp.

Dandy J.E., 1980, Triglochin L., [in:] Tutin T.G., Heywood V.M., Burges N.A., Moore D.M., Valentine D.H., Walters S.M., Webb D.A. (eds), Flora Europaea. Vol. 5: Alismataceae to Orchidaceae (Monocotyledones), Cambridge Univ. Press, Cambridge: 7-11.

Davy A. J., Bishop G. F., 1991, Biological flora of the British Isles: no.172, List Br. Vasc. PL. (1958) No. 574, 2. Triglochin martima L. ( Triglochin martimum L.), J. Ecol. 79: 531-555.

Guo Y., Haynes R.R., Hellquist C.B., 2010, Juncaginaceae, [in:] Wu Z.Y., Raven P.H., Hong D.Y. (eds), Flora of China. Vol. 23: Acoraceae through Cyperaceae, Science Press and Missouri Botanical Garden Press, Beijing-St. Louis, p. 105. Retrieved from http://www.efloras.org [accessed 27 April 2017].

Haynes R.R., Les D.H., Holm-Nielsen L.B., 1998, Juncaginaceae, [in:] Kubitzki K. (ed.), The families and genera of vascular plants. Vol. 4. Flowering plants: Monocotyledones: Alismatanae and Commelinanae (except Gramineae), Springer, Berlin-New York: 260-263.

Haynes R.R., 2004, Juncaginaceae, [in:] Smith N., Mori S.A., Henderson A., Stevenson D.W., Heald S.V. (eds), Flowering Plants of the Neotropics, New York Botanical Garden, Princeton University Press, Princeton: 452-453.

Harris J.G., Harris M.W., 1994, Plant identification terminology: An illustrated glossary, Spring Lake Publishing Co., Spring Lake, $216 \mathrm{pp}$.

Hegi G., 1981, Illustrierte Flora von Mitel-Europa, Bd. I/2: Gymnospermae. Angiospermae. Monocotyledonae 1, Verlag Paul Parey, Berlin-Hamburg, 269 pp.

Hill T.G., 1900, The structure and development of Triglochin martimum L., Ann. Bot. 14: 83-107.

Holm-Nielsen L.B., Haynes R.R., 1986, 191. Alismataceae/192-197. Limnocharitaceae, Hydrocharitaceae, Juncaginaceae, Potamogetonaceae, Zannichelliaceae, Najadaceae, [in:] Harling G., Sparre B. (eds), Flora of Ecuador no 26, 
Swedish Natural Science Research Council, Stockholm: 3-24 / 37-82.

Jafri S.M.H., 1977, Juncaginaceae, [in:] Ali S.I., Jafri S.M.H. (eds), Flora of Libya. Vol. 11, Al-Faateh University, Tripoli: $1-4$.

Kondracki J., 1994, Geografia Polski: Mezoregiony fizycznogeograficzne (Geography of Poland: Physico-geographical mesoregions), Wydaw. Nauk. PWN, Warszawa, 304 pp (in Polish).

Kondracki J., 2002, Geografia regionalna Polski (Regional geography of Poland), Wydaw. Nauk. PWN, Warszawa, 441 pp (in Polish).

Kubitzki K. (ed.), 1998, The families and genera of vascular plants. Vol. 4. Flowering plants: Monocotyledones: Alismatanae and Commelinanae (except Gramineae), Springer, Berlin-Heidelberg, 511 pp.

Lisowski S., Malaisse F., Symoens J.J., 1982, Flore d'Afrique Centrale (Congo-Kinshasa, Rwanda, Burundi), Spermatophytes, Juncaginaceae, National Botanic Garden of Belgium 51: 1-6.

Mądalski J., 1977, Atlas Flory Polskiej i Ziem Ościennych / Florae polonicae terrarumque adiacentium iconographia. Vol. 2/1: Alismataceae, Butomaceae, Hydrocharitaceae, Juncaginaceae, Zannichelliaceae, Potamogetonaceae, Najadaceae, PWN, Warszawa-Wrocław, 94 pp (in Polish and Latin).

Miluniec R., Leciej K., Łuczyk D., Miluniec D., 2005, Program ochrony środowiska dla gminy Nowe Warpno. Załącznik do Uchwały NR XXXIV/166/2005 Rady Miejskiej w Nowym Warpnie z dnia 28 czerwca 2005 roku w sprawie „Programu Ochrony Środowiska dla Gminy Nowe Warpno", Nowe Warpno (Program of the environmental protection for the municipality of Nowe Warpno. Attachment to the Resolution No. XXXIV/166/2005 of the Nowe Warpno City Council of 28 June 2005 on the "Environmental Protection Program for the Commune of Nowe Warpno") [typescript], NFOŚ-ZTUK w Szczecinie, Szczecin, 88 pp (in Polish). Retrieved from http:// www.bip.nowewarpno.pl/pobierz/200 [accessed 30 April 2017].

Mowszowicz J., 1977, Pospolite rośliny naczyniowe Polski (Common vascular plants of Poland), PWN, Warszawa, 680 pp (in Polish).

Raciborski M., Szafer W. (eds), 1919, Flora Polska. Rośliny naczyniowe Polski i ziem ościennych. T. I: Paprotniki, iglaste i jednoliścienne (Flora of Poland. Vascular plants of Poland and adjacent territories. Vol. I: Pteridophyta, coniferae and monocotyledones), Akad. Umiej., Kraków, 427 pp (in Polish).

Raunkiaer C., 1934, The life forms of plants and statistical plant geography, Clarendon Press, Oxford, 632 pp.
Rutkowski L., 1998, Klucz do oznaczania roślin naczyniowych Polski niżowej (Key to the determination of vascular plants of lowland Poland), Wydaw. Nauk. PWN, Warszawa, 816 pp (in Polish).

Sotek Z., 2001, Distribution of Triglochin martimum (Juncaginaceae) in Poland, Fragm. Flor. Geobot. 45(1-2): 445-456.

Spjut R.W., 1994, A systematic treatment of fruit types, Mem. New York Bot. Gard. 70: 1-182.

Stevens P.F., 2001, Angiosperm Phylogeny Website. Version 12, July 2012 [and more or less continuously updated since]. Retrieved from http://www.mobot.org/MOBOT/ research/APweb/ [accessed 27 April 2017].

Szafer W., Kulczyński S., Pawłowski B., 1986, Rośliny polskie. Opisy i klucze do oznaczania wszystkich gatunków roślin naczyniowych rosnących w Polsce dziko, bądź zdziczałych lub częściej hodowanych, Cz. 2 (Polish plants. Descriptions and keys to the identification of all species of vascular plants growing in Poland whether wild, escaped from cultivation or commonly cultivated, Part 2), PWN, Warszawa: 465-1019 (in Polish).

Szennikow A., 1952, Ekologia roślin (Plant ecology), PWRiL, Warszawa, 385 pp (in Polish).

Szweykowska A., Szweykowski J., 2006, Botanika. T. 2: Systematyka (Botany. Vol. 2: Systematics), Wydaw. Nauk. PWN, Warszawa, 638 pp (in Polish).

Takhtajan A., 2009, Flowering plants, Springer, New York, 871 pp.

Thorn R.F., 1992, Classification and geography of flowering plants, Bot. Rev. 58(3): 225-348.

Toma C., 2008, Studium karpologiczne gatunków z podklasy Alismatidae (rząd Helobiae) występujące w Polsce (Carpological study of species of Alismatidae subclass (Helobiae ordo) occurring in Poland), Ser. Pr. Zakładu Taksonomii Roślin UAM 17, Bogucki Wydaw. Nauk., Poznań, 120 pp (in Polish).

Tomlinson P.B., 1982, Anatomy of the monocotyledons. Vol. 7: Helobiae (Alismatidae) (including the seagrasses), Clarendon Press, Oxford, 559 pp.

Tootill E. (ed.), 1984, The Penguin dictionary of botany, Penguin UK, London, 400 pp.

Walters S.M., 1980, Alismataceae, [in:] Tutin T.G., Heywood V.M., Burges N.A., Moore D.M., Valentine D.H., Walters S.M., Webb D.A. (eds), Flora Europaea. Vol. 5: Alismataceae to Orchidaceae (Monocotyledones), Cambridge Univ. Press. Cambridge.

Wu H-Y., Su X. , Chen W., Dong L-N., Yang X., Sun K.., 2008, Floral organogenesis of Triglochin maritimum Linn. (Juncaginaceae), Bull. Bot. Res. 28(6): 653-656. 